\title{
DEVELOPMENT OF INTERDISCIPLINARY INSTRUCTION USING INQUIRY BASED SCIENCE EDUCATION
}

\author{
Eva Trnova \\ Faculty of Education, Masaryk University (Czech Republic)
}

\begin{abstract}
The task of current educational system is to give all students competences they will need to prosper in global economic competition. However, students very often consider learning content as useless for their everyday life. In the context of natural sciences, this is not only about the choice of learning content but also about the way in which science subjects are taught. Students are not usually able to connect knowledge from individual natural science subjects and to solve interdisciplinary problems so typical for everyday life. It could be one of important reasons of lack of student interest in study of natural sciences. However, teachers are not usually educated in interdisciplinary instruction and they do not know appropriate educational methods supporting interdisciplinarity. Inquiry based science education is one of suitable educational strategies for interdisciplinary teaching/learning. Research findings confirming the effectiveness of pre-service teacher education in interdisciplinary instruction using IBSE are presented.
\end{abstract}

Keywords: Interdisciplinary instruction, inquiry based science education, teacher education.

\section{Introduction}

Current educational systems of developed countries have many tasks according to priorities of individual countries. But the main ones include providing all students competencies they will need to prosper in global economic competition during their professional life and to equip them for solving everyday problems. Scientific knowledge very quickly develops and grows and subsequently scientific progress has an influence on everyday life of people. In particular, the development of natural sciences significantly affects people's lives. But natural science educators especially in Europe and USA face the decline of interest in the study of natural science and technology (OECD, 2006; Kires \& Šveda, 2012).

Educational experts and researchers try to find reasons for this phenomenon (Bolte, 2006; Dostal, 2015). Unsuitable educational methods appear to be one of the main factors leading to this situation (Rocard et al., 2007). According to PISA findings only $15 \%$ of European students are satisfied with the quality of natural science teaching/learning in schools and nearly $60 \%$ state that natural science teaching/learning is not interesting for them (Ministry of Education, Youth and Sports CR, 2010). One of significant reasons of lack of student interest in study of natural sciences could be traditional educational strategies which very often prefer acquisition of separate knowledge such as data, formulas, equations, theories, etc., that students only memorize without understanding and forget them very easily (Ministry of Education, Youth and Sports CR, 2010).

Very important reason, why students consider natural science school subjects useless, is that they are not usually able to connect knowledge from separate natural science subjects and to solve interdisciplinary problems so typical for everyday life. According to our research findings, even though students think natural science educational contents are important for society, on the other hand they consider them unnecessary for their everyday life (Trnova, 2012). Based on ours and above mentioned research findings it is necessary to innovate educational strategies of natural science instruction and to take into consideration interdisciplinary attitude supporting student motivation and deeper understanding. According to research findings (Trnova, 2014) Inquiry Based Science Education (hereafter IBSE) is appropriate for interdisciplinary instruction of natural science subjects.

\section{Rationale}

Teachers are a significant factor affecting student learning outcomes (Darling-Hammond, 2000; Osborne, \& Dillon, 2008). Therefore, it is very important to pay attention to their education, beginning in pre-service education and ongoing throughout their continuing professional development (hereafter CPD). 
It is necessary to educate them how to carry out interdisciplinary instruction to satisfy students' requirements for linking teaching/learning to everyday life. They do not often know educational strategies suitable for interdisciplinary instruction or they are not able to implement them into natural science instruction.

Teachers' professional competences have to be created through three main parts: pre-service education, in-service education and practical school experience (see Fig. 1). The high educational level of the three components mentioned in Fig.1 and their linking are important conditions for quality teacher education. Teachers take part in this educational system in five possible roles: teacher as learner, teacher as teacher, teacher as reflective practitioner, teacher as leader and teacher as researcher. The role of teacher-learner is typical for teacher-candidates. This role is often underestimated and neglected during continuing professional development (CPD). But it is very important because according to experts, teachers are strongly influenced by their own school experience as learners and many teachers have minimum experience with interdisciplinary teaching/learning from their schooling.

The role of teacher-teacher is connected with teacher's classroom practice and university students (pre-service teachers) go through this role during teacher training at schools. The role of teacher-reflective practitioner is based on experience and is expected at the level of the CPD. Teacher-leader is involved in teacher training management and this role is usually fulfilled by experienced teachers or education specialists (expert in didactics, educationalist, etc.). Currently action research is very popular. Researchers of our University engage in-service teachers (some pre-service teachers as well) in action research as much as possible. It is beneficial for both sides - university experts and teachers.

Figure 1. A diagram of systematic teacher education (Trnova, 2014).

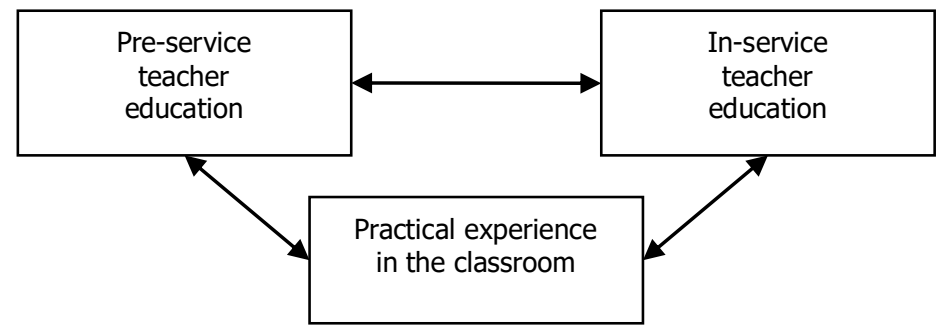

\subsection{Interdisciplinarity}

Interdisciplinary instruction is generally defined as the integration of two or more disciplines. The term "interdisciplinary" is applied to a variety of curricular arrangements and has got a variety of synonyms (multi-disciplinary, transdisciplinary, thematic teaching, integrated learning). The degree of integration and what will be integrated is very important to consider. Relan and Kimpston (1991) arrange interdisciplinary approaches to the curriculum along a continuum of operational schemes, indicating the degree of integration. Thus, one extreme of the continuum would be structuring the curriculum plan around each separate subject, with the opposite extreme being an "eclectic" or "problem-oriented" approach. Techniques such as the intermingling of disciplines (sometimes called "multi-disciplinary") or the integration of across-the-domain skills such as problem-solving or writing across the curriculum are between these opposite poles.

In the Czech Republic pre-service teachers are usually educated in two separate subjects of their choice and interdisciplinary instruction is on the edge of interest. But current multidisciplinary paradigm of natural science education requires an integrated approach. Faculty of Education at Masaryk University in Brno solves this deficiency in the pre-service teacher education and establishes the course Didactics of Natural Sciences which is aimed to interdisciplinary instruction. Students (teacher-candidates) acquire educational strategies appropriate for interdisciplinary instruction. First, they get to know them theoretically and then apply them in practice at schools.

\subsection{Inquiry Based Science Education (IBSE)}

IBSE also belongs to strategies which are relatively new in the Czech Republic, and therefore students (teacher candidates) and teachers have usually minimum experiences with IBSE instruction and they have to gain them. According to our research findings (Jeskova, Kires, Ganajova, \& Kimakova, 2011; Trnova, 2012) teachers are able to implement IBSE in appropriate way when they acquire it in both roles (teacher as learner and teacher as teacher) under supervision. After they can develop their acquired professional skills in next roles. But it is necessary to show teachers how to develop interdisciplinarity within IBSE. Not every IBSE learning content includes an interdisciplinary dimension. Interdisciplinarity 
places demands on teachers not only in the field of didactics, but also in other sciences that they do not have in their teaching qualifications. Teachers themselves must understand the interdisciplinary issues that pupils should learn through IBSE.

Teachers must learn to collaborate with colleagues to prepare an interdisciplinary instruction. Teamwork is very important for quality interdisciplinary teaching/learning and it enriches all participants in the educational process. In Faculty of Education at Masaryk University in Brno students learn this skill in the frame the course Didactics of Natural Sciences. They create interdisciplinary teams, members are experts in individual natural sciences and they collaborate to prepare quality interdisciplinary topics. University teachers, experts in natural sciences, didactics, pedagogy, etc. are in the role of mentors. This interdisciplinary teaching/learning can facilitate students to learn about approaches, theories and methodologies from various disciplines of the social and natural sciences.

\section{Methodology}

The aim of the research was to verify the development of interdisciplinary instruction of natural science subjects using IBSE. The research was focused on education of in-service teachers, pre-service-teachers and pupils' educational outcomes. Considering limited scope, this study presents only research findings connected with education of pre-service teachers. Therefore, the research question is:

How IBSE implementation in pre-service teacher training influences development of interdisciplinary instruction?

The research sample was composed of 36 students (pre-service science teachers) from Faculty of Education, Masaryk University, the Czech Republic. These students were preparing for interdisciplinary instruction using IBSE in the course Didactics of Natural Sciences. During this course students gained experience with interdisciplinary instruction using IBSE first in the role as learners. It means they carried out inquiry, fulfilled tasks as pupils in order that they could better imagine feelings or learning problems of children. In this role they also acquired the necessary pedagogical knowledge and skills for teaching. After that students in the role of teachers realized interdisciplinary instruction using IBSE under the guidance of experienced teachers during their practice at schools. Pre-service teachers built up their pedagogical knowledge, skills and competences using their own experience from the role as learners and after during practice at schools as teachers, they connected pedagogical theory and practice, which is known as teacher constructivism (Magoon, 1977). The university teachers of natural science subjects were in the role teacher-leader and teacher- researcher.

A research-method of triangulation (semi-structured interviews, questionnaire and analysis of teachers-candidates' products) was used as a specific method to answer above mentioned research question. First, semi-structured interviews were carried out with all (36) research participants and questions were focused on the professional competences connected with development of interdisciplinary instruction using IBSE. Based on the answers of research participants, items of questionnaire using Likert scale were created (Pulpan, \& Kulicka, 2015). The verification of the research findings was completed using the analysis of educational products created by research participants. The collected data were analysed. The research was conducted in the period 2016-2017.

\section{Results}

As mentioned above, the questions in the semi-structured interviews were focused on competences of pre-service science teachers connected with interdisciplinary instruction using IBSE. Research participants stated what professional competences connected with interdisciplinary instruction using IBSE they had acquired during the course. In the next research tool - questionnaires - research participants expressed their subjective assessment of the extent of acquired professional competences. To determine the level of acquisition, the 5-point Likert-type rating scale (1-Very weakly, 2-Weakly, 3-Normally, 4-Strongly, 5-Very strongly) to measure development of their professional competences were used. Tab. 1 provides an overview of the main professional competences mentioned by pre-service science teachers. Subsequently, analysis of teachers-candidates' products and verification of collected data were performed.

Results of the questionnaire are presented in Table 1. The collected data showed that the main pre-service teacher professional competences for interdisciplinary teaching were developed significantly. If we consider only the highest category Very strongly of the Likert scale, this option was chosen by more than a half of respondents for four professional pedagogical competences important for interdisciplinary instruction (to motivate pupils, to encourage students to solve interdisciplinary problems, include interdisciplinary topics from everyday life relevant to pupils, to develop lifelong learning skills). 
The great development of most of respondents' monitored professional pedagogical competences is even more apparent, when the category strongly and very strongly is combined. In this case, except of "integration of natural science and social issues in interdisciplinary instruction", pre-service teachers stated significant development of their professional competences for interdisciplinary instruction. It was confirmed by research findings of pupil educational outcomes and analysis of educational products created by research participants.

Research findings confirm the quality of teacher education is reflected in the quality and effectiveness of education (Pellegrino, \& Hilton, 2012; Osborne, Simon \& Collins, 2003; European Commission, 2004). According to experts, teachers are the significant factor influencing learning outcomes of pupils ((Darling-Hammond, 2000; Osborne \& Dillon, 2008). Based on these facts and the presented research findings, it is possible to answer the research question How IBSE implementation in pre-service teacher training influences development of interdisciplinary instruction? Because teacher competences were developed, it is possible to confirm development of interdisciplinary instruction using IBSE. IBSE implementation in teaching/learning supports development of interdisciplinarity. Our next research results (pupil outcomes and analysis of educational products created by research participants) confirmed this conclusion as well.

Table 1. Pre-service teachers' questionnaire - data.

\begin{tabular}{l|c|c|c|c|c|c}
\hline \hline $\begin{array}{l}\text { Using IBSE in } \\
\text { interdisciplinary } \\
\text { instruction I am able to: }\end{array}$ & $\begin{array}{c}(1) \\
\text { Very weakly } \\
(\%)\end{array}$ & $\begin{array}{c}(2) \\
\text { Weakly } \\
(\%)\end{array}$ & $\begin{array}{c}(3) \\
\text { Normally } \\
(\%)\end{array}$ & $\begin{array}{c}(4) \\
\text { Strongly } \\
(\%)\end{array}$ & $\begin{array}{c}(5) \\
\text { Very } \\
\text { strongly } \\
(\%)\end{array}$ & $\begin{array}{c}\text { Mean } \\
\text { values }\end{array}$ \\
\hline $\begin{array}{l}\text { motivate pupils for natural } \\
\text { science }\end{array}$ & 0 & 0 & 0 & 31 & 69 & 4,69 \\
\hline $\begin{array}{l}\text { encourage pupils to solve } \\
\text { interdisciplinary problems }\end{array}$ & 0 & 0 & 0 & 42 & 58 & 4,58 \\
\hline $\begin{array}{l}\text { include interdisciplinary } \\
\text { topics from everyday life } \\
\text { relevant to pupils }\end{array}$ & 0 & 0 & 3 & 39 & 58 & 4,56 \\
\hline $\begin{array}{l}\text { develop lifelong learning } \\
\text { skills }\end{array}$ & 0 & 0 & 8 & 36 & 56 & 4,47 \\
\hline $\begin{array}{l}\text { develop skills of pupils to } \\
\text { connect information from } \\
\text { different natural science } \\
\text { subjects }\end{array}$ & 0 & 0 & 0 & 58 & 42 & 4,42 \\
\hline $\begin{array}{l}\text { integrate natural science } \\
\text { and social issues in } \\
\text { interdisciplinary } \\
\text { instruction }\end{array}$ & 0 & 0 & 20 & 36 & 44 & 4,25 \\
\hline $\begin{array}{l}\text { develop pupils' } \\
\text { interdisciplinary } \\
\text { experimentation }\end{array}$ & 0 & 0 & 8 & 73 & 19 & 4,11 \\
\hline \hline
\end{tabular}

\section{Conclusions}

In the frame of the course Didactics of Natural Sciences advantages and disadvantages of interdisciplinary instruction were defined. Pre-service teachers were led to reduce impact of disadvantages and effectively used advantages. IBSE was confirmed as appropriate strategy for development of interdisciplinary instruction. Main advantages are listed in Table1. It is necessary to highlight the development of lifelong learning skills that are essential to pupils' future education as well as their lives and future success, and increasing of pupil ability to solve interdisciplinary problems. According to outcomes of the course, advantages of interdisciplinary instruction for teachers are: collegial environments, high level of innovativeness, high levels of energy and enthusiasm, support for personal growth and learning.

Considering that quality of teachers is the fundamental factor affecting learning outcomes, it is necessary to pay a lot of attention to their education, especially in the area of innovative educational strategies. To increase the effectiveness of science teacher education, it is necessary to implement innovations already into pre-service teacher education. It is important for teacher-candidates to construct their professional pedagogical skills based on experience acquired first as learners and later as teachers 
with support of experienced teachers and experts. This method of teacher constructivism connects teachers' own experience from instruction with pedagogical knowledge and skills and creates high-quality professional pedagogical competences.

The presented research findings confirm that a properly implemented innovative component in pre-service teacher education can improve the quality of professional competences and teachers are not afraid of its implementation in their teaching. During pre-service training students should have possibility to acquire core knowledge and skills connected with innovative educational strategies, which they do not experience during their studies. The presented pre-service teacher education in the course Didactics of Natural Sciences could be example how to educate future teachers of natural science subjects.

\section{References}

Bolte, C. (2006). As Good as It Gets: The MoLE Intrument for the Evaluation of Science Instruction. Paper presented at the Annual Meeting of the National Association for the Research on Science Education (NARST), San Francisco, USA: Polyscript.

Darling-Hammond, L. (2000). Teacher Quality and Student Achievement. A Review of State Policy Evidence, Education Policy Analysis Archives.

Dostál, J. (2015). The Draft of the Competencial Model of the Teacher in the Context of the Inquiry-Based Instruction. Procedia-Social and Behavioral Sciences, 186, 998-1006.

European Commission. (2004). Europe needs More Scientists. Report by the High Level Group on Increasing Human Resources for Science and Technology.

Jeskova, Z., Kires, M., Ganajova, M., \& Kimakova, K. (2011). Inquiry-based learning in science enhanced by digital technologies. In Emerging eLearning Technologies and Applications (ICETA), 9th International Conference (pp. 115-118). IEEE

Kires, M., \& Šveda, D. (2012). Scientific literacy for the information society. In Emerging eLearning Technologies \& Applications (ICETA), 2012 IEEE 10th International Conference (pp. 193-196). IEEE.

Magoon, A. J. (1977). Constructivist approaches in educational research. Review of Educational Research, 47(4), 651-693.

Ministry of Education, Youth and Sports CR. (2010). Talent nad zlato. Retrieved February 20, 2015 from: http://userfiles.nidm.cz/file/ KPZ/KA1-vyzkumy/brozura-talentnadzlato-web.pdf

Organisation for Economic Cooperation and Development (OECD). (2006). Evolution of student interest in science and technology studies: Policy report. Paris: OECD.

Osborne, J., \& Dillon, J. (2008). Science Education in Europe: Critical Reflections. The Nuffield Foundation, London. Retrieved February 20, 2015, from http://hub.mspnet.org/index.cfm/ 15065

Osborne, J., Simon, S., \& Collins, S. (2003). Attitudes towards science: A review of the literature and its implications. International journal of science education, 25(9), 1049-1079.

Pellegrino, J. W., \& Hilton, M. L. (2012). Education for life and work: developing transferable knowledge and skills in the 21 st century. Washington, D.C.: National Academies Press.

Půlpán, Z., \& Kulička, J. (2015). The fuzzy intuitive sets in the decision-making. International Journal of Engineering Technology and Computer Research, 3(2), 76-180.

Relan, A. \& Kimpston, R. (1991). Curriculum Integration: A Critical Analysis of Practical and Conceptual Issues, Annual Convention of the American Educational Research Association.

Rocard, M., Cesrmley, P., Jorde, D., Lenzen, D., Walberg-Herniksson, H., \& Hemmo, V. (2007). Science education NOW: A Renewed Pedagogy for the Future of Europe. Brussels, Belgium: Office for Official Publications of the European Communities. Retrieved February 25, 2015 from http://ec.europa.eu/research/science-society/document_library/pdf_06/report-rocardon-scienceeducation_en.pdf.

Trnová, E. (2012). Teacher Development in IBSE. In Badania w dydaktyce chemii (pp. 181-184). Krakow, Poland: Pedagogical University of Krakow

Trnova, E. (2014). Systemic teacher continuous professional development as support of teaching practice. in Frontiers in Mathematics and Science Education Research, pp. 204-211. 